\title{
Analytical model for friction piles in consolidating soft soils
}

\author{
Modelo analítico para pilotes de fricción en suelos \\ blandos en proceso de consolidación
Juan Félix Rodríguez Rebolledo ${ }^{*} \quad$ Gabriel Auvinet Guichard ${ }^{2}$
Recibido 28 de agosto de 2017, aceptado 03 de junio de 2018
Received: August 28, 2017 Accepted: June 03, 2018

\begin{abstract}
In this paper, a simplified analytical model for the design of friction piles foundations in an environment that is prone to regional subsidence is presented. The model is based on Mindlin's equations and was originally proposed by Reséndiz and Auvinet. Some important modifications of the original version based on the results obtained from numeric analyses have been introduced. In this new version, negative skin friction is evaluated taking into consideration initial and future effective stresses conditions and not only the limit shear strength of the soil in contact with the pile system. The model was validated with results previously obtained by the authors using the Axisymmetric Finite Element Method. In spite of the differences observed during such validation, it was possible to conclude that a reasonably good match exists between both models.
\end{abstract}

Keywords: Friction piles, pile group, regional subsidence, Mexico City clay.

\section{RESUMEN}

En este trabajo se presenta un modelo analítico simplificado para el diseño de cimentaciones a base de pilotes de fricción en un entorno propenso a hundimiento regional. El modelo se basa en las ecuaciones de Mindlin y fue propuesto originalmente por Reséndiz y Auvinet. Se realizaron algunas modificaciones importantes a la versión original, basadas en los resultados obtenidos de análisis numéricos. En esta nueva versión, la magnitud de la fricción negativa se evalúa considerando, tanto las condiciones iniciales y futuras de los esfuerzos efectivos, como la resistencia al corte límite del suelo en contacto con el sistema de pilotes. El modelo fue validado con resultados obtenidos previamente por los autores mediante el Método de Elementos Finitos Axisimétricos. A pesar de las diferencias obtenidas durante dicha validación, fue posible concluir que existe una concordancia razonable entre los resultados arrojados por ambos modelos.

Palabras clave: Pilotes de fricción, grupos de pilotes, hundimiento regional, arcilla de la Ciudad de México.

\section{INTRODUCTION}

In the soft soils of Mexico City, friction piles have been used to reduce settlements (design in term of deformation), most commonly as part of a box-type foundation. Less frequently, they have been used to support the total load of the structure and ensure the stability of the foundation (design in terms of bearing capacity). In all cases, a complex interaction develops between the subsoil, the piles

\footnotetext{
1 Programa de Pós-graduação em Geotecnia. Universidade de Brasília. Edifício SG-12, Departamento de Engenharia Civil e Ambiental. Faculdade de Tecnologia. Campus Universitário Darcy Ribeiro. CEP 70910-900. Brasília DF, Brasil. E-mail: jrodriguezr72@unb.br

2 Instituto de Ingeniería. Universidad Nacional Autónoma de México. Torre de Ingeniería, Circuito Escolar s/n, Ciudad Universitaria, Coyoacán. CP 04510. Ciudad de México, México. E-mail: gauvinetg@iingen.unam.mx

* Corresponding author
} 
and the structure. The subsoil is subjected to a double consolidation process: one of them induced by the weight of the structure and the other by the decrease of pore water pressure caused by the intense pumping of the groundwater of the city that induces regional subsidence.

Because of the complexity of the problem and of the considerably high number of parameters involved, few analytical methods have been developed for the analysis and design of friction pile foundations subjected to external loads and soil consolidation due to variations in piezometric conditions. Most of them are simplifications aiming at evaluating the magnitude of negative skin friction [1, 4, 7-8], some of them take into account the interaction between the two consolidation processes [13, 21], and a few of them consider the current knowledge of the problem obtained from numerical modelling $[3,15-16]$, and/or laboratory or field tests $[4,9]$.

This paper is the continuation of the research developed by the authors presented in [16], where the behavior of friction pile foundations in typical Mexico City soft clays, subjected to external loads and soil consolidation due to variations in piezometric conditions was studied using numerical analyses. In this part of the investigation, a simplified analytical model, originally proposed by Reséndiz and Auvinet [13] based on Mindlin's equations [10], is further developed and validated against the results obtained in the numerical analyses mentioned above.

The aim of this paper is to provide an alternative and validated tool that can be used for the design of friction piles foundation in an environment that is prone to regional subsidence.

First, some background information regarding the description of the parametric studies performed with the numerical modeling [16] is provided. Next, a brief description of the original analytical model [13] is presented. Then, the proposed modifications based on the numerical modeling results are exposed and, finally, the validation of the new analytical model is presented.

\section{NUMERICAL MODELLING}

Parametric studies were performed for a foundation slab on friction piles [16] driven in Mexico City soft clay, which were assumed to be $25 \mathrm{~m}$ long (down to $4 \mathrm{~m}$ above hard layer) and $0.5 \mathrm{~m}$ in diameter. The weight of a typical five to ten floor building was considered applying a load of 75 $\mathrm{kPa}$ directly to the rigid slab. The analyses were developed in three stages. In Stage 1, pile was placed (no installation effects were considered, but the pile weight was taken into account as discussed below) and the $75 \mathrm{kPa}$ load was applied on the slab; in Stage 2 a first pore pressure drawdown was introduced (Figure 1a), simulating typical future piezometric conditions; and in Stage 3 a second pore pressure drawdown was considered (Figure 1b), representing an extreme, but possible, future piezometric condition in Mexico City. The conditions at the end of each stage of the analysis, after the excess pore pressure due to the applied load and pore pressure drawdown has been completely dissipated were assessed.

A group of friction piles, connected to an infinitely large rigid slab was considered (Figure 2a). The simulations dealt with the long term behavior of the internal piles. The hexagonal tributary area of each internal pile was idealized as a circular unit cell (Figure 2a). The radius of the tributary area is then equal to half of the centre-to-centre spacing between piles. The problem can then be represented by an axisymmetric model (Figure $2 b$ ).

Vertical displacements of the foundation for different relative spacing S/D (centre to centre spacing vs. pile diameter) were predicted using different constitutive models: an elastic-perfectly plastic Mohr-Coulomb model, and three hardening elasto-plastic models: the Modified Cam Clay [17] and Soft Soil [5] models (both isotropic) and the S-CLAY1 model (anisotropic) [18] able to account for the high yielding anisotropy that is typical for Mexico City clay. The obtained results are described in [16] and some of them will be presented further ahead for validation purposes of the analytical model.

\section{ORIGINAL ANALYTICAL MODEL DESCRIPTION}

The procedure to evaluate the behavior of a system of friction piles, initially proposed by Reséndiz and Auvinet [13] and implemented by Auvinet and Díaz-Mora [2], is as follows: 


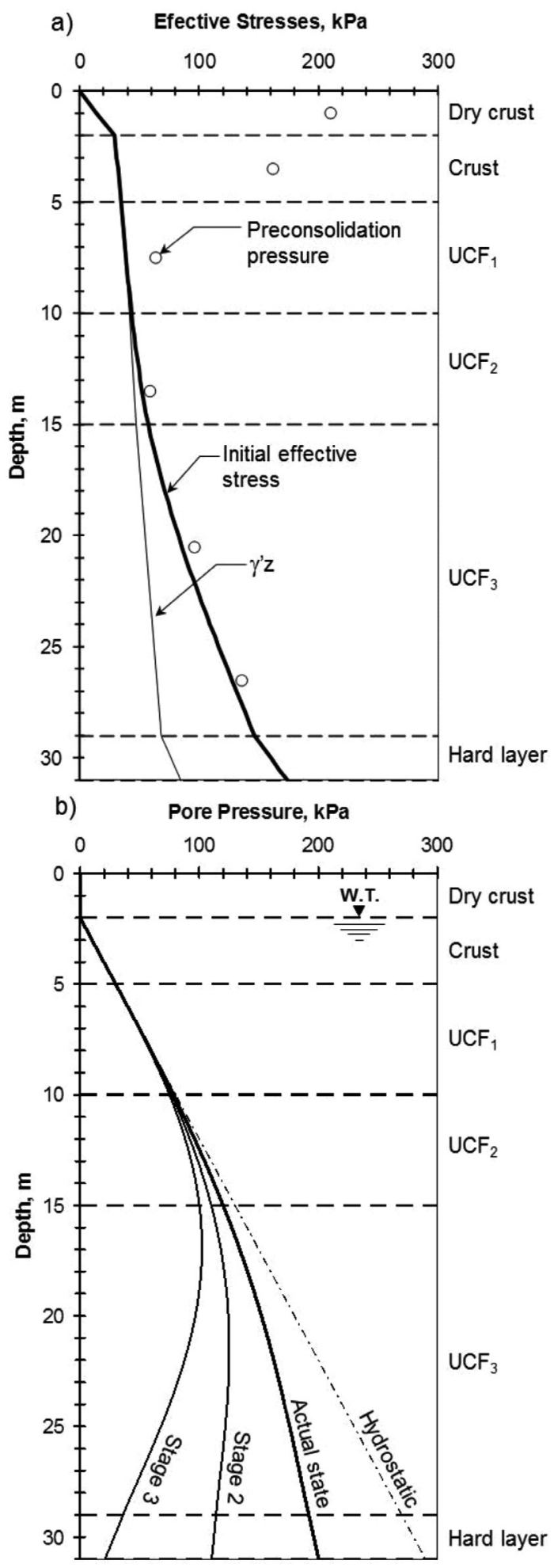

Figure 1. Initial effective stress and pore water pressure profiles for the numerical model (source: [16]).

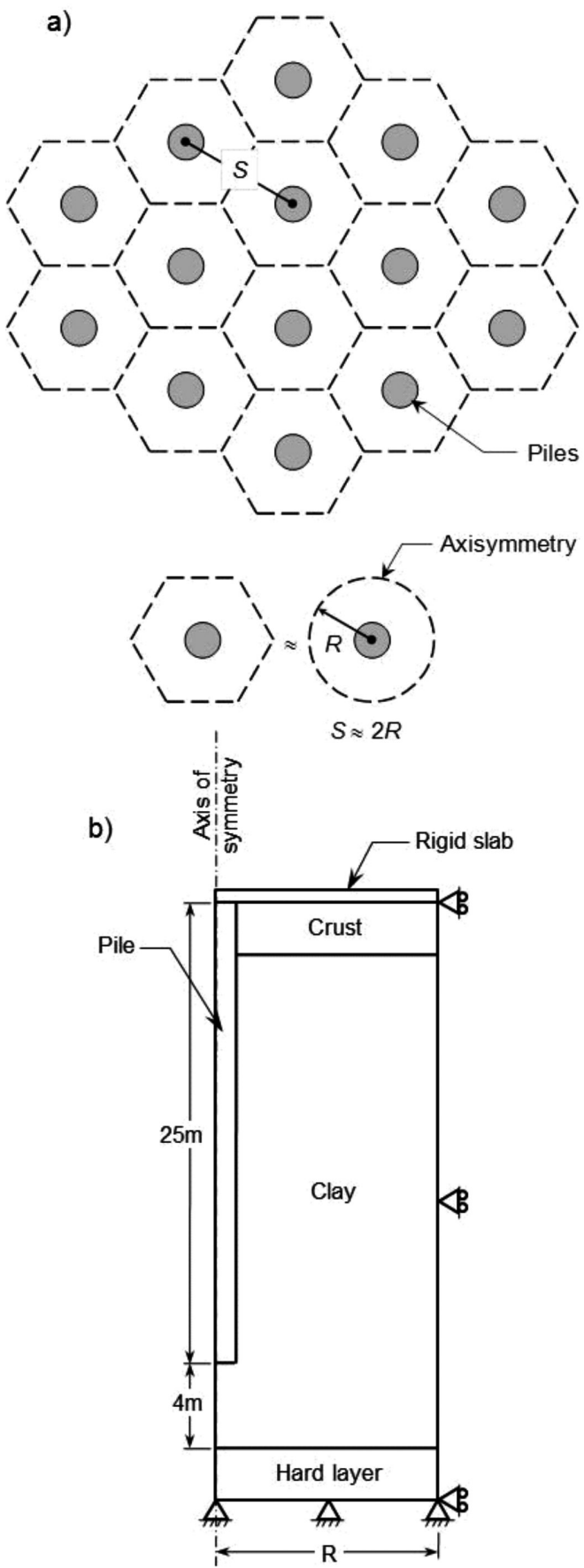

Figure 2. Model of a pile raft. a) Infinitely large pile raft supported by friction piles. b) Numerical model (not to scale, source: [16]).

Step 1. The in situ vertical effective stress distribution within the soil mass is evaluated based on unit weights and in situ pore pressure. 
Step 2. The long term load $(R)$ on the caps of the pile system is calculated by equation (1):

$$
R=\min \left(\Sigma Q, R_{p}+R_{f}^{+}\right)
$$

where $\Sigma Q$ is the total long term load (weight of structure + piles + average service load), $R_{p}$ is the system point bearing capacity and $R_{f}^{+}$is the positive skin friction, computed from the limit shear strength of the soil in contact with the pile system.

When $R=\Sigma Q$, piles take the total applied load and hence a neutral level is able to develop. It is possible to verify this behavior with the developed numerical models. Figure 3a shows the variation of the axial load developed in the pile $\left(Q_{\text {pile }}\right)$ over the applied load $(\Sigma Q)$ with depth, for $S / D=3$, as predicted by the numerical model (S-CLAY1 model). It is observed that the applied load is transmitted completely to the pile cap $\left(Q_{\text {pile }} / \Sigma Q\right.$ $=1$, for depth $=0)$ and a neutral level $\left(y_{0}\right)$ develops at a depth of $23 \mathrm{~m}$.
On the other hand, when $R=R_{p}+R_{f}^{+}$, piles are unable to take the entire applied load because limit conditions prevail at tip and along the shaft of the piles. Then neutral level is unable to develop and the substructure (superficial slab or box-type foundation) transmits part of $\Sigma Q$ directly to the soil.

Step 3. The force resulting from the total substructuresoil contact pressure is calculated as, equation (2):

$$
P=\Sigma Q-R
$$

Step 4. The position of the neutral level $\left(y_{0}\right)$ is found by trial and error until equation (3) is satisfied:

$$
R-R_{p}=\left|R_{f}^{+}\right|_{y_{o}}^{y_{p}}-\left|R_{f}^{-}\right|_{D_{f}}^{y_{o}}
$$

where $R_{f}^{-}$is the negative skin friction, and $y_{P}, y_{0}$ and $D_{f}$ are the depths of the pile tip, neutral level and slab, respectively. In this case, $R_{f}^{-}$is computed from the limit shear strength of the soil in contact
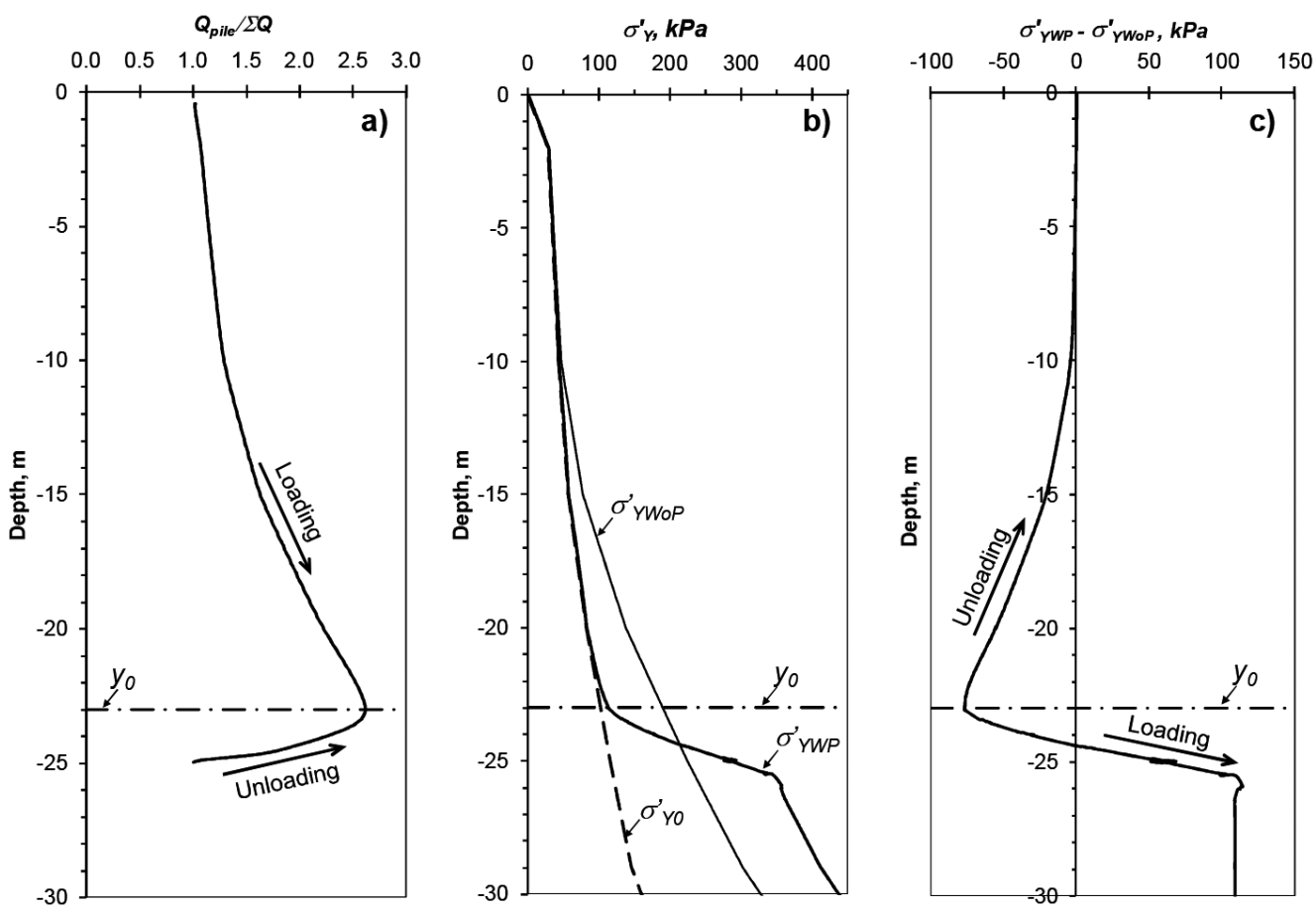

Figure 3. a) Axial load developed in the pile; b) $\sigma_{Y O}^{\prime}=$ initial effective stress, $\sigma^{\prime}{ }_{Y W o P}=$ final vertical effective stress without piles and $\sigma_{Y W P}^{\prime}=$ final vertical effective stress with piles; and c) effective vertical stresses increment regarding $\sigma^{\prime}{ }_{Y W o}$ developed around the pile. For $S / D=3$ as predicted by S-CLAY1. 
with the pile system and taking into account that the drag force on a particular pile within a large group of piles cannot be larger than the weight of the surrounding soil contained in the tributary volume of the pile.

Step 5. An equivalent averaged stress field is obtained replacing the positive and negative skin friction ( $R_{f}^{+}$and $R_{f}^{-}$), the substructure (superficial slab or box-type foundation)-soil contact force $(P)$ and the tip forces $\left(R_{p}\right)$ by equivalent vertical uniformly distributed loads (acting on a horizontal plane), located at different depths, as shown in Figure 4. Using a numerical technique such as the generalized sectors method [12] or an exact solution [18] for integration of Mindlin's equations [10], the stresses induced at any depth by the vertical distributed loads, are calculated.

Step 6. The consolidation settlements induced by the effective stress variations caused by the vertical equivalent distributed loads and the considered future pore pressure drawdown, are estimated using compressibility curves obtained from laboratory consolidation tests (void ratio $v s$. effective stress).

\section{a) When $R=\Sigma Q$}

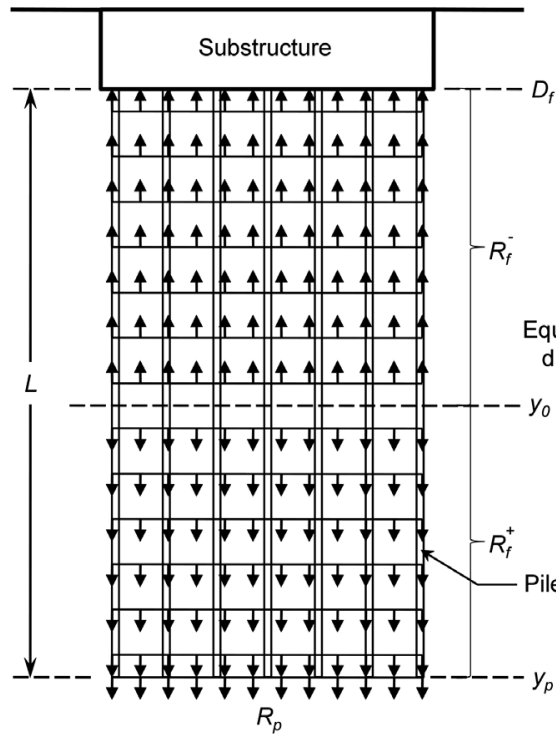

\section{PROPOSED MODIFICATIONS}

It appears that the analytical model above (Step 4) might overestimate the negative skin friction effects. As a matter of fact, negative skin friction cannot be larger than the apparent increase of the buoyant weight of the soil mass surrounding the pile above the neutral level, due to seepage forces induced by the pore pressure drawdown $[3,15]$. This can be simply taken into account introducing equation (4) in equation (3) (Step 4) [3, 15]:

$$
\left|R_{f}^{-}\right|_{D_{f}}^{y_{o}}=\min \cdot\left\{\begin{array}{c}
C_{f} \mid \begin{array}{c}
y_{o} \\
D_{f}
\end{array} N_{P} \\
\Delta \sigma_{y_{o}} A_{T}
\end{array}\right\}
$$

where $C_{f} \mid \begin{gathered}y_{0} \\ D_{f}\end{gathered}$ is the lateral bearing capacity developed from $D_{f}$ thru $y_{0}, N P$ is the number of piles, $\Delta \sigma_{y 0}$ is the effective stress increment at $y_{0}$ (without piles) developed by the potential future pore pressure drawdown and $A_{T}$ is the total tributary area between piles. This assumption can also be verified using the developed numerical models.

Figure $3 b$ shows the variations of the obtained vertical effective stresses with depth in the

b) When $R=R_{p}+R_{f}^{+}$

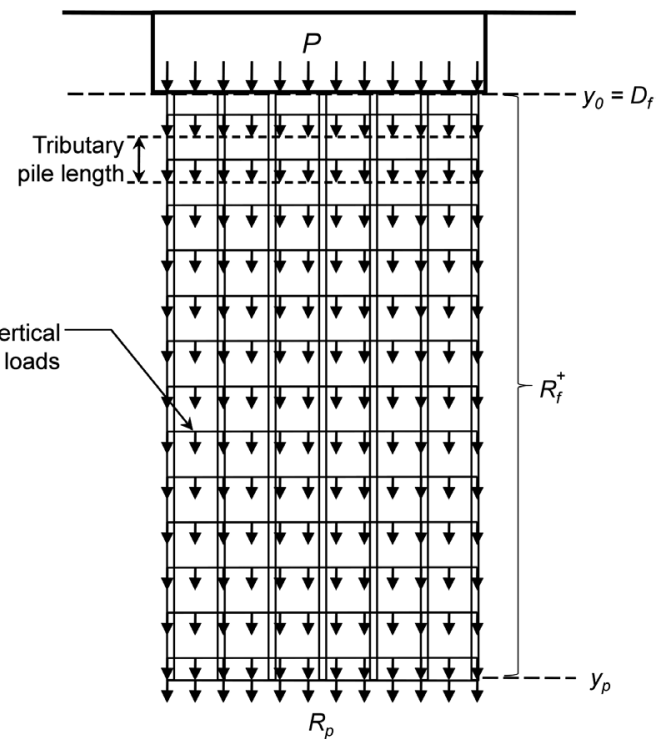

Figure 4. Positive and negative skin friction $\left(R_{f}^{+}\right.$and $\left.R_{f}^{-}\right)$, tip forces $\left(R_{p}\right)$ and substructure (superficial slab or box-type foundation)-soil contact force $(P)$ replaced by equivalent vertical distributed loads acting on a horizontal plane. 
surrounding soil far away from the pile shaft (at $S / 2$ from the pile center) at the end of stage 3 (when induced excess pore pressure has completely dissipated), where $\sigma_{Y 0}^{\prime}$ is the initial effective stress, $\sigma_{Y W_{O} P}^{\prime}$ is the final vertical effective stress without piles and $\sigma_{Y W P}$ is the final vertical effective stress with piles. It can be observed that no incremental effective stresses are induced in the surrounding soil above $y_{0}$. This means that the incremental effective stresses induced by pore pressure drawdown $\left(\sigma_{Y W o P}^{\prime}-\sigma_{Y 0}^{\prime}\right)$ is taken by the pile shaft above $y_{0}$ (pile loading, Figure $3 \mathrm{a}$, and soil unloading, Figure 3c) and transmitted to the soil by the pile tip and the pile shaft below $y_{0}$ (pile unloading, Figure 3a, and soil loading, Figure 3c).

\section{VALIDATION OF THE MODIFIED MODEL}

In the following, the analytical model is applied to the cases simulated by numerical analyses presented in [16]. Table 1 shows the mean values of the soil constants used in the analytical model, which correspond to the values in [16], obtained from [19] database. For practical purposes, the pile friction and the point bearing capacity were estimated from the mean values of $c_{u}$ obtained from unconsolidated-undrained triaxial tests. Drained or consolidated-undrained tests are rarely performed on Mexico City clay simply because of the excessively long consolidation times. Also, in the previous analyses [16] it has been concluded that for long-term analyses the compressibility behavior of the reinforced soil mass is more relevant than the pile-soil interaction. The adhesion factor for friction pile estimation was assumed to be equal to one $(\alpha=1,[11])$. The initial effective stresses and the pore pressure conditions are the same as in the numerical studies [16], Figure 1.

To simulate the behavior of an internal pile within a large pile group, similarly to the numerical analyses which considered an infinite raft, an arbitrary large square foundation $(200 \times 200 \mathrm{~m})$ is considered, and the displacements and stresses are computed in the center of the foundation. The validation of the analytical model is made by comparing the results with those obtained by numerical modelling.

Figure 5 shows the predicted relative displacements for different $S / D$ values and for the three analyzed stages. In this figure the results obtained from the numerical models are included, the gray bands represents the range of values obtained in [16] with the hardening elastoplastic constitutive models (S-CLAY1, Soft Soil and Modified Cam-Clay). Although qualitatively the results are the same, the analytical model predicts larger apparent protrusion than the numerical models, especially for low $S / D$ values. There are three main reasons that explain such differences:

1) In the analytical model, the point load and positive skin friction are computed from the limit shear strength, while in the numerical models this is not totally true for small pile spacing, given that the mobilization of strength depends on the predicted displacements.

2) The prediction of the compressibility in the analytical model is a function of the vertical effective stress only, while in the numerical models the compressibility is predicted from the

Table 1. Soil constants values used in the analytical model.

\begin{tabular}{|c|c|c|c|c|c|c|c|}
\hline Layer & Depth m & $\gamma \mathbf{k N} / \mathbf{m}^{\mathbf{3}}$ & $c_{u} \mathrm{kPa}$ & $\mathbf{e}_{0}$ & $\mathbf{C}_{\mathrm{c}}$ & $\mathbf{C}_{\mathrm{r}}$ & $P O P \mathrm{kPa}$ \\
\hline Dry crust & $0-2$ & 14.5 & 125 & 1.8 & 0.6 & 0.06 & 196 \\
\hline Crust & $2-5$ & 12.0 & 60 & 5.4 & 4.5 & 0.29 & 130 \\
\hline $\mathrm{UCF}_{1}$ & $5-10$ & 11.4 & 28 & 8.7 & 7.7 & 0.47 & 25 \\
\hline $\mathrm{UCF}_{2}$ & $10-15$ & 11.1 & 33 & 10.0 & 7.6 & 0.53 & 5 \\
\hline $\mathrm{UCF}_{3}$ & 15-29 & 11.5 & 70 & 7.2 & 6.3 & 0.33 & 10 \\
\hline $\begin{array}{ll}\gamma= & \text { un } \\
c_{u}= & \text { un } \\
e_{0}= & \text { in } \\
C_{c}= & \text { sl } \\
C_{r}= & \text { sl } \\
P O P= & \text { ve }\end{array}$ & $\begin{array}{l}\text { weight. } \\
\text { ained she } \\
\text { al void rat } \\
\text { e of the no } \\
\text { e of the sv }\end{array}$ & $\begin{array}{l}\text { trength. } \\
\text { al compr } \\
\text { ing line }\end{array}$ & $\begin{array}{l}\text { sion lin } \\
\text { he } \log \end{array}$ & the & $\sigma^{\prime}-$ & plane. & \\
\hline
\end{tabular}




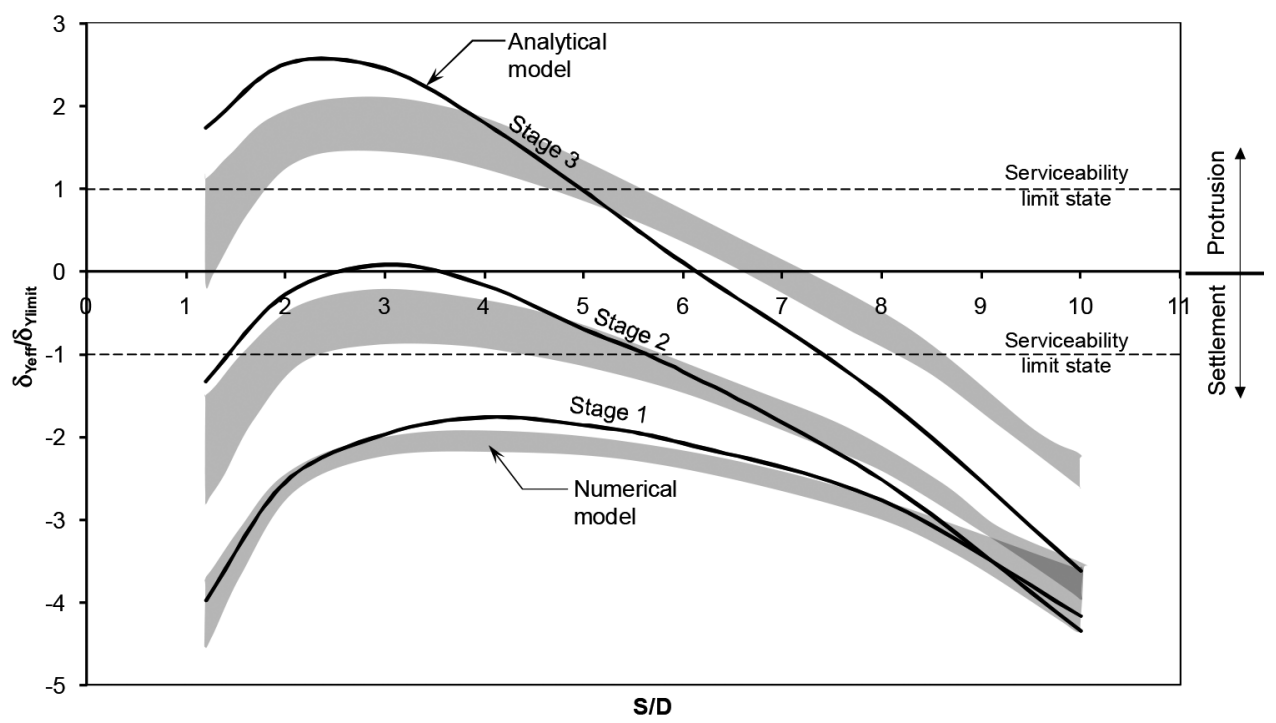

Figure 5. Comparison of the effective vertical displacement ratios predicted by the analytical and numerical models.

mean effective stress, and hence the effective horizontal stresses influence the results.

In spite of the above, it is possible to say that a reasonably good match between analytical and numerical models has been obtained. Figures 6 and 7 shown the predicted increments of vertical effective stress $\left(\Delta \sigma^{\prime}{ }_{y}\right)$ obtained in the soil around the pile for the analytical and the S-CLAY1 models, for $S / D=3$ and 8 , respectively, and for the three stages of analysis. Reasonable agreement between vertical effective stresses is also observed.

The modified analytical model can thus be considered as a simple and potentially useful tool. An important advantage of this model is that it can also be used for three dimensional analyses. This model is presently being calibrated by comparison with three dimensional numerical models taking into account the larger negative skin friction that may develop on the perimeter piles.

\section{CONCLUSIONS}

A simplified analytical model based on Mindlin's equations was proposed and validated with results obtained by numerical modelling. A reasonable match between the analytical and numerical models was obtained. The analytical model can thus be

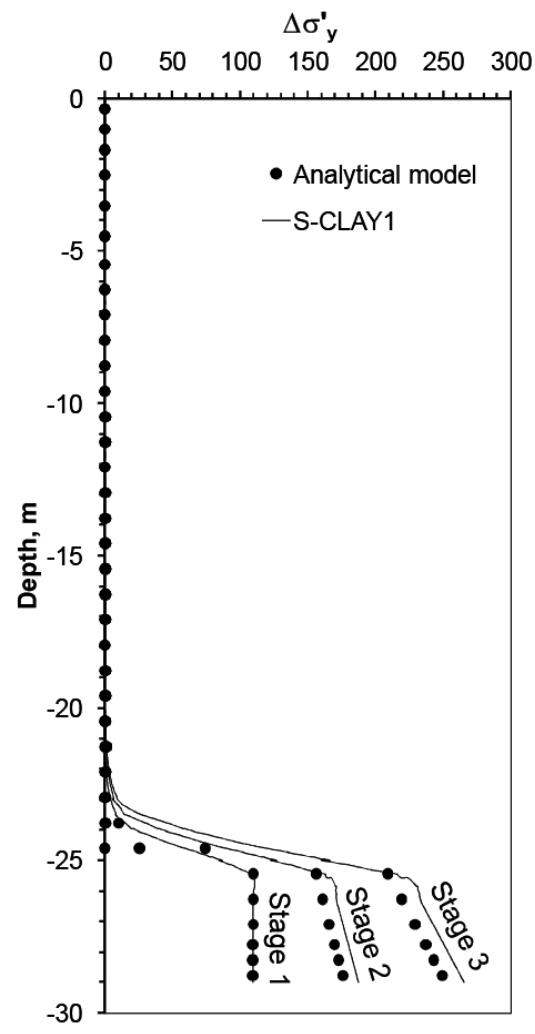

Figure 6. Predicted increments of vertical effective stress for the analytical model and S-CLAY1 model for $S / D=3$ (Stages 1 to 3 ). 


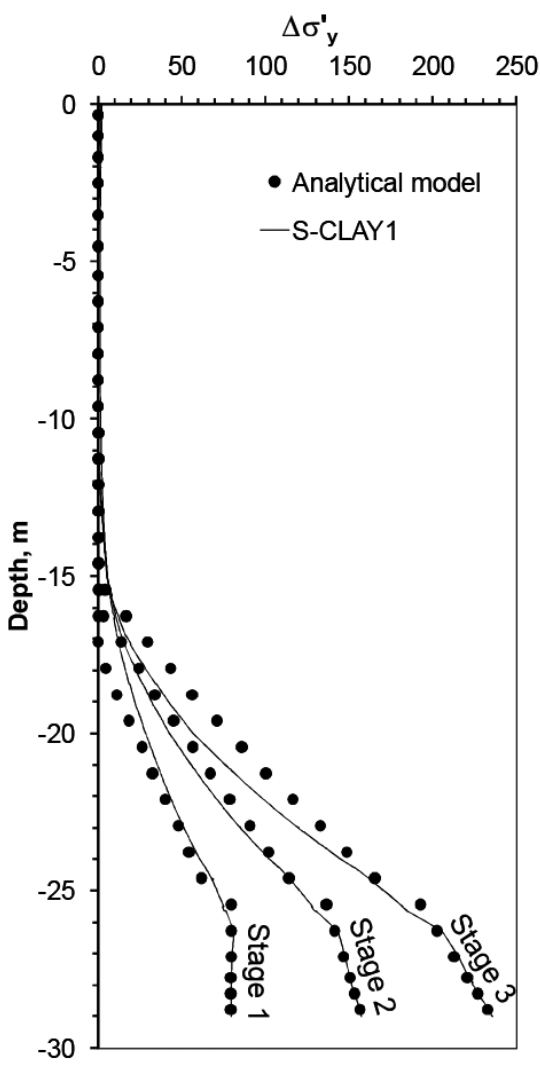

Figure 7. Predicted increments of vertical effective stress for the analytical model and S-CLAY1 model for $S / D=8$ (Stages 1 to 3 ).

considered as a simple and potentially useful tool. An advantage of this model is that it can also be used for three dimensional analyses. This model is presently being calibrated by comparison with three dimensional numerical models taking into account the larger negative skin friction that may develop on the perimeter piles.

\section{ACKNOWLEDGMENTS}

The authors acknowledge the Coordination for the Improvement of Higher Education (CAPES) and the National Council for Scientific and Technological Development (CNPq) for their support and partnership.

\section{REFERENCES}

[1] J. Alberro and R. Hernández. "Proceso de consolidación y fricción negativa inducida, en pilas, pilotes y muros". Series del Instituto de
Ingeniería, UNAM. No 619.2000 . URL: https:// aplicaciones.iingen.unam.mx/ConsultasSPII/ DetallePublicacion. asp $x$ ?id $=481$

[2] G. Auvinet y C. Díaz Mora. "Programa de computadora para predecir movimientos verticales de cimentaciones". Series del Instituto de Ingeniería, UNAM. No 438. May 1981. URL: https://aplicaciones.iingen.unam.mx/ ConsultasSPII/DetallePublicacion.aspx?id=323

[3] G. Auvinet and J.F. Rodríguez Rebolledo. "Criteria for the design of friction piles subjected to negative skin friction and transient loads". Ingenieria Investigacion y Tecnologia. Vol. $18 \mathrm{~N}^{\circ}$ 3, pp. 279-292. July/ September 2017. ISSN: 1405-7743. URL: http://www.ingenieria.unam.mx/ revistafi/ numeros/2017/v18n3-05.pdf

[4] J.L. Briaud, S. Jeong and R. Bush. "Group efect in the case of downdrag". Proc. ASCE Geotechnical Engineering Congress. Colorado, USA. 1991.

[5] R.B. Brinkgreve "Geomaterial models and numerical analysis of softening". Ph. D. theses. Delft University of Technology. Delft, the Netherlands. 1994.

[6] M Endo, A. Minou, T. Kawasaki and T. Shibata. "Negative skin friction acting on steel pipe pile in clay". Proc. 7th ICSMFE. Mexico City, Mexico. 1969.

[7] O. Combarieu. "Frottement négatif sur les pieux". Laboratoire Central des Ponts et Chaussées. Research report. No 136. 1985.

[8] S. Jeong, S. Kim and J.L. Briaud. "Analysis of downdrag on pile groups by the finite element method". Comp. and Geotech. J. Vol. $21 \mathrm{~N}^{\mathrm{o}}$ 2, pp. 143-161. 1997.

[9] C.F. Leung. "Negative skin friction on piles". Proc. Indian Geotechnical Conference. Guntur, India. 2009.

[10] R.D. Mindlin. "Force at a point in the interior of a semi-infinite solid". J. Appl. Physics. Vol. 7, pp. 195-202. 1936.

[11] E. Ovando. "Direct shear tests on Mexico City clay with reference to friction pile behavior". Geotech. Geolo. Eng. J. Vol. 13, pp. 1-16. 1995.

[12] H.G. Poulos and E.H. Davis. "The use of the sector method for calculating stresses and displacements in an elastic mass. Elastic solutions for Soil and Rock Mechanics". Series in Soil Engineering. Wiley. 1974. 
[13] D. Reséndiz and G. Auvinet. "Analysis of pile foundations in consolidating soils". Proc. 8th ICSMFE. Moscow, Russia. 1973.

[14] E. Rodríguez. "Análise experimental do comportamento de sistemas Radier estaqueado em solos moles em procesos de adensamento". Ph. D. theses, Programa de Pos-Graduação em Geotecnia, Universidade de Brasilia. Brasila, Brazil. 2016.

[15] J.F. Rodríguez. "Modelado del comportamiento de pilotes e inclusiones sometidos a consolidación regional, en la zona lacustre de la Ciudad de México". Ph. D. thesis. Programa de Maestría y Doctorado en Ingeniería, UNAM. Mexico City, Mexico. 2011.

[16] J.F. Rodríguez, G. Auvinet y H.E. Martínez. "Settlement analysis of friction piles in consolidating soft soils". DYNA. Vol. 82 No 192, pp. 211-220. Jun/July 2015. ISSN: 0012-7353. DOI: http://dx.doi.org/10.15446/ dyna.v82n192.47752.
[17] K.H. Roscoe and J.B. Burland. "On the generalized stress-strain behavior of "wet" clay". Engineering Plasticity, in: Heyman, J. and Leckie, F.A. eds. Cambridge University Press. pp. 535-609. 1968.

[18] O. Rossa and G. Auvinet. "Stress induced by surficial and deep loading in an elastic medium". J. Geotech. Engng, ASCE. Vol. 118 $\mathrm{N}^{\mathrm{o}}$ 8, pp. 1241-1246. 1992.

[19] SIG. Sistema de Información Geográfica. Laboratorio de Geoinformática, Instituto de Ingeniería, UNAM. Mexico City, Mexico. 2012. URL: http://sitios.iingen.unam.mx/ geoinformatica/

[20] S.J. Wheeler, A. Näätänen, M. Karstunen, and M. Lojande. "An anisotropic elastoplastic model for soft clays". Can. Geotech. J. Vol. 40, pp. 403-418. 2003. DOI: http:// dx.doi.org/10.1139/t02-119.

[21] L. Zeevaert. "Foundation Engineering for difficult subsoil conditions". New York: Van Nostrand Reinhold Company. New York, USA. 1973. 